\title{
Holiday Price Rigidity and Cost of Price Adjustment*
}

\author{
By DANIEL LEVY,† GEORG MÜLLER, $\ddagger$ HAIPENG (ALLAN) CHEN, †† \\ MARK BERGEN,杖 and SHANTANU DUTTA†††
}

†Bar-Ilan University and Rimini Center for Economic Analysis $\quad \ddagger$ Monitor Group

†Texas A\&M University $\quad$ \$University of Minnesota

$\dagger+\dagger$ University of Southern California

Final Version: May 6, 2008

The Thanksgiving-Christmas holiday period is a major sales period for US retailers. Due to higher store traffic, tasks such as restocking shelves, handling customers' questions and inquiries, running cash registers, cleaning, and bagging, become more urgent during holidays. As a result, the holiday-period opportunity cost of price adjustment may increase dramatically for retail stores, which should lead to greater price rigidity during holidays. We test this prediction using weekly retail scanner price data from a major Midwestern supermarket chain. We find that indeed, prices are more rigid during holiday periods than non-holiday periods. For example, the econometric model we estimate suggests that the probability of a price change is lower during holiday periods, even after accounting for cost changes. Moreover, we find that the probability of a price change increases with the size of the cost change, during both, the holiday as well as non-holiday periods. We argue that these findings are best explained by higher price adjustment costs (menu cost) the retailers face during the holiday periods. Our data provides a natural experiment for studying variation in price rigidity because most aspects of market environment such as market structure, industry concentration, the nature of long-term relationships, contractual arrangements, etc., do not vary between holiday and nonholiday periods. We, therefore, are able to rule out these commonly used alternative explanations for the price rigidity, and conclude that the menu cost theory offers the best explanation for the holiday period price rigidity.

JEL Codes: $\quad$ E12, E31, L16, L11, M31

Key Words: Price Rigidity, Cost of Price Adjustment, Menu Cost, Holiday Period, Asymmetric Price Adjustment, Monetary Policy 


\section{INTRODUCTION}

"It's a madhouse during the holidays. There is no time to do anything that is marginal or incremental-you have to focus on the essential issues, keeping items in stock, keeping the registers manned, and making the store presentable. The key is to manage the flow of goods and customers through the store.”

Brett Drey, Retail Manager

Holidays are arguably the most important sales periods for US retailers. For example, Warner and Barsky (1995) suggest that the Thanksgiving-Christmas period is the busiest shopping period. Chevalier, et al. (2003, p. 20) focusing on the consumption of food, state that “... Christmas and Thanksgiving represent the overall peak shopping periods for Dominick’s.” Indeed, our conversations with supermarket managers indicate that these two holiday periods constitute the busiest shopping period in their stores.

In this paper we focus on pricing decisions during this holiday season. There is a literature that studies pricing patterns during holiday periods, which focuses on the increase in demand during holiday periods—studying how firms incorporate these demand effects into higher or lower price levels during holiday periods (see, e.g., Pashigian and Bowen 1991, Warner and Barsky 1995, and Chevalier, et al. 2003). This emphasis on the demand side and its implications for holiday pricing is interesting and important.

We explore a missing piece in this literature-supply side issues during holiday periods_-by focusing on the cost of price adjustment during holiday periods. We argue that the costs of price adjustment increase during holidays. Due to higher store traffic, other tasks such as restocking shelves, handling customers’ questions and inquiries, running cash registers, cleaning, and bagging, become more urgent during holidays and thus receive priority, which increases the opportunity costs of price adjustment. This observation is consistent with the existing evidence on price adjustment processes and their costs in the retail industry (e.g., Levy, et al. 1997). Indeed, statements made by retail 
pricing managers confirm that their opportunity cost of price adjustment increases dramatically during holiday periods.

The most direct implication of higher costs of price adjustment should be nominal price rigidity (Mankiw, 1985; Ball and Mankiw, 1994). Thus, we expect to see greater price rigidity during holiday periods. We test this hypothesis using weekly scanner data set consisting of retail and wholesale prices for thousands of products at a large US supermarket Chain, Dominick's. Indeed, we find greater price rigidity during the holiday periods in comparison to the non-holiday periods, as predicted by the menu cost theory.

Much of the recent theoretical work on price rigidity relies on cost of price adjustment ("menu costs") as a critical theoretical lynchpin (Blinder, et al., 1998). However, very little is known about the actual empirical relevance of these costs. According to Fisher and Konieczny (2006) and Konieczny and Skrzypacz (2004), the empirical evidence supporting the menu cost theory is mixed, although some studies that use high and moderate inflation period data such as Lach and Tsiddon (1996), provide evidence consistent with it. However, some studies, e.g., Carlton (1986), report findings of frequent small price changes which appear to go against the simple menu cost theory. ${ }^{1}$

Two empirical studies that offer direct evidence on the relevance of menu costs (Levy, et al. 1997, and Owen and Trzepacz, 2002) use variation in regulatory environment in the form of item pricing laws and the resource costs necessitated by their requirements, to demonstrate that higher price adjustment costs lead to greater price rigidity. The current study documents variation in price rigidity between holiday and nonholiday periods, and contributes to that literature by demonstrating the critical importance of price adjustment costs for price rigidity. Our findings, therefore, reinforce the likely importance of costs of price adjustment as a source of price rigidity, at least in the retail multi-product setting. 
This finding also complements the existing literature that studies variations in price rigidity across dimensions such as time, markets, and products. ${ }^{2}$ We add to this literature by documenting an additional form of heterogeneity in price rigidity- variation in price rigidity across holiday and non-holiday periods. This is particularly valuable because it occurs within just a one-year period of time. As such, it offers a natural experiment because most factors that have been traditionally proposed as explanations for price rigidity, such as variation in industry concentration, in implicit and/or explicit contracts, in the nature of long-term relationships, or in the market structure, do not vary within the year between holiday to non-holiday periods. ${ }^{3}$

The paper is organized as follows. In section I, we briefly discuss our theoretical prediction. In section II, we describe the data. In section III we report the findings. In section IV we discuss and rule out alternative explanations. We conclude in section V.

\section{THEORETICAL PREDICTION}

Our theoretical prediction is fairly straightforward. We argue that the costs of price adjustment increase during holidays, drawing on managerial insights and the existing studies of price adjustment costs. This observation leads to our hypothesis - that retail prices should be more rigid during holiday periods in comparison to the rest of the year.

The initial insight about higher holiday price adjustment costs came from discussions with retail price managers. The conversations we had with them confirm the existence of higher costs of price adjustment during holidays. For example, Bob Venable, an expert in the supermarket industry, stated that: 
resources are spent on other tasks, and the value of price changes is lower here.”

Debra Farmer, manager of a large supermarket, provided the following description of the difficulties her organization faces when it comes to changing prices during holidays:

\begin{abstract}
“Changing prices during the Thanksgiving and Christmas holidays? That's very difficult. We do not have enough people to do that. It is almost impossible. During regular weeks, we restock the shelves during late night and early morning hours. But during these holidays, we have to do it every hour; we do not have enough manpower to do that.”
\end{abstract}

Lisa Harmening, a manager at a large packaged goods manufacturer stated that:

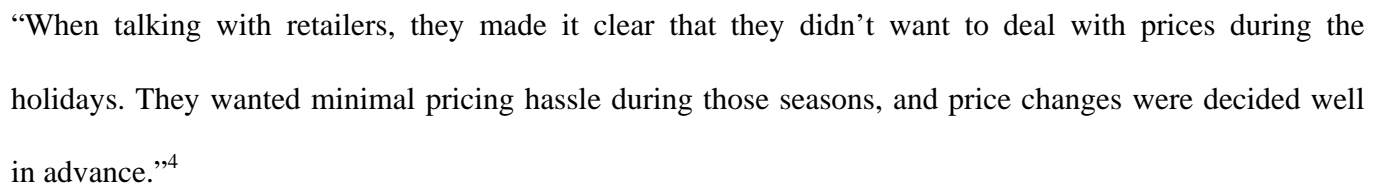

Consistent with this anecdotic evidence, the existing studies of costs of price adjustment (i.e., “menu costs”) at large U.S supermarkets identify the labor input as the most important component of price adjustment costs. For example, Levy, et al. (1997, 1998; Dutta, et al. 1999; Bergen, et al. 2008) document in detail the process these retailers follow to adjust prices. They find that the resources that go into the price change process consist of mostly labor input, and include the time spent on (1) price tag change preparation, (2) removing old price tags and putting up new price tags, (3) verifying that the price changes were done correctly, and (4) correcting mistakes. Further, they report that this process is very labor intensive. Indeed, according to the measurements of Levy, et al. (1997, p. 800) for large U.S super-market chains, labor cost “... is the single largest component of the menu costs... making up about 70.1 percent of the total menu costs for 
these chains on average." ${ }^{5}$ Thus, labor costs of changing prices are the largest component of menu costs in these establishments.

During the holiday season the opportunity cost of using employee time to change prices rather than perform other tasks rises substantially. This is due to the larger volume of customer traffic during holidays. At the retailer we study, the volume of items sold increases $6 \%$ on average during holidays. The increase in the number of shoppers necessitates that more labor time be used for running the cash registers, restocking the shelves, cleaning, handling customers' questions and inquiries, bagging, etc. Since the goodwill of customers is affected by these activities (Oliver and Farris, 1989), retailers emphasize these activities to maintain their goodwill during the busy holiday periods.

An additional reason for the increase in the opportunity cost of price adjustment during the holidays is the increase in the costs of mistakes that occur during the price change process. When prices are changed, the new price needs to be posted in both the shelf label and in the cash register database. Often mistakes are made leading to a mismatch between the shelf and the price programmed in the cash register. Levy, et al. (1997) report that the costs of pricing mistakes, which include (1) lost cashier time, (2) scan guarantee refunds, and (3) stock-outs (if the shelf price is lower than intended), comprise about 19 percent of the total costs of price adjustment. The cost of pricing mistakes increases during holidays because the lines at cash registers are longer and a "price check" will create greater delay and dissatisfaction among customers.

Retailers could resolve this labor shortage difficulty by hiring temporary workers. However, according to Debra Farmer, a manager of a large supermarket,

“... it is difficult to find temporary workers for the weeks of these two holidays because the high school and college students, which is the group from which the supermarkets usually hire their temporary workers for 
the summer months, are not available during these holiday weeks."

Unable to adjust the number of workers during holiday periods, supermarkets try to adjust the number of hours worked. ${ }^{7}$ Many of their workers are employed on a part time basis and during holidays they are asked to add extra hours for which they are paid overtime wage rates. ${ }^{8}$ But these extra labor hours are not used to change prices. ${ }^{9}$ Instead, according to Ms. Farmer, they are used to perform other, more urgent tasks like, packing bags, opening extra cash registers, bringing products from storage rooms to shelves, checking prices, and customer service. Workers are routinely moved from task to task as needed. For example, Shayne Roofe, the manager of a Harp’s Food Store in Rector, AR, is trained to use a key-cutting machine located in the store (Progressive Grocer, February 1993, p. 43). Similarly, according to Jack Koegel, the President of Twin Value Foods headquartered in Green Bay, Wis., “... he and his executives are not averse to doing such chores as mopping a floor, if necessary” (Progressive Grocer, October 1992, p. 56).

Thus, the workers employed by the supermarket chains are always busy and the opportunity cost of changing price is positive. During the holiday periods, the opportunity costs increase substantially, making price changes more costly. We, therefore, predict that prices will be more rigid during holiday periods in comparison to the rest of the year.

\section{DATA}

Our dataset contain product-level retail price and wholesale price scanner data from a large supermarket chain, Dominick’s which operates 94 stores in the Greater Chicago metropolitan area with a market share of about 25 percent (Hoch, et al., 1995). ${ }^{10}$ The 
chain is similar to other large, multiple-store supermarket chains currently selling in the U.S. In 1992, large supermarket chains of this type made up \$310.1 billion in total sales, which constituted about 86.3\% of total supermarket chain sales in 1992 (Supermarket Business, 1993), or about 14 percent of the total US retail sales of $\$ 2.25$ trillion.

\section{Insert Table 1 about here}

The data set we have assembled consists of product-level retail prices and wholesale prices for over 4,500 products in 18 product categories. ${ }^{11}$ In Table 1 we list the product categories and the number of products for which data were available in each category. The data are weekly, and reflect actual prices the consumers pay at the cash register for each product studied; the retail prices in this dataset are not aggregated in any way. The data cover the period from the week of September 14, 1989 to the week of September 16, 1993, a total of 210 weeks, where a week is defined from Thursday to Wednesday. Having weekly time series offers an important advantage for studying price-setting behavior in a market where the actual pricing cycle is also weekly (Levy, et al., 1997, 1998; Slade, 1998).

Our price and cost data come from a subset of 9 stores of the chain. ${ }^{12}$ Dominick's has three price zones, and each store belongs to one of the zones. Six of the 9 stores sampled are in the mid-price zone. The other three stores are located in the low-price zone. The chain defines the store type based on the competitive environment the store faces. Thus

the stores belonging to the mid-price tier face similar competitive environments. ${ }^{13}$ Prices for all stores within the chain are set centrally at corporate headquarters and implemented by the stores.

The weekly retail price data come from the scanner database of the supermarket 
chain. The prices are the posted shelf prices, and are usually the same as the transaction prices. ${ }^{14}$ Price changes are performed once per week (on Wednesday nights), which is the standard practice in this industry. Thus, the price data we use are the actual shelf prices in effect in the given week.

The weekly wholesale price data also come from the chain’s scanner database and represent a weighted average of the amount the retailer paid for their entire inventory held in a given week. ${ }^{15}$ The wholesale price data do not include lumpy payments like slotting allowances, manufacturer-provided services such as direct store delivery, or other manufacturer-level support. However, our discussions with pricing managers indicate that they rely on these wholesale price series to make their pricing decisions. Other studies in this context (e.g., Hoch, et al. 1995, Barsky, et al. 2003, and Chevalier, et al. 2003) confirm this observation. Further, our discussions with managers indicate that the use of the lumpy-payment schemes does not vary systematically between holiday and non-holiday periods, which are the focal interest of this study. For more details about the data, see Barsky, et al. (2003).

There are many holidays throughout the year, but few are as closely associated with retail sales in the U.S. as Thanksgiving and Christmas. Following Barsky and Warner (1995) and Chevalier, et al. (2003), we define the week before Thanksgiving through the week of Christmas, a total of six week period, as the holiday period in each year. ${ }^{16}$

\section{ECONOMETRIC ESTIMATION RESULTS}

Our data allow us to test the hypothesis of increased holiday price rigidity using two notions of price rigidity employed in the existing literature. First, we examine price rigidity indirectly by studying the frequency of price changes. However, as Blinder 
(1991, pp. 93-94) suggests, "From the point of view of macroeconomic theory, frequency of price changes may not be the right question to ask. We are more interested to know how long price adjustments lag behind shocks to demand and costs." Indeed, according to the Carlton and Perloff's (1994) definition, "Price rigidity is said to occur when prices do not vary in response to fluctuations in costs and demand" (p. 722).

The availability of the cost (i.e., wholesale price) data enables us to examine this, more direct, notion of price rigidity as well. To accomplish this, we construct and estimate a probabilistic regression model that incorporates the magnitude of cost change along with "promotions" variable, which might influence the likelihood of a price change, in addition to the increased holiday period demand.

Frequency of retail price changes

As a first test of our hypothesis, we compare the mean number of price changes performed each week, per store, by category, during holiday and non-holiday periods. Table 2 reports the results, along with the percentage difference. In the last column of the table we report the $t$-statistic for testing the null hypothesis that the average numbers of weekly price changes during holiday and non-holiday periods are equal against the alternative that the average number of price changes decreases during the holiday period.

\section{Insert Table 2 about here}

With the exception of just two categories (canned soups and snack crackers), the average number of price changes per week during holidays is lower in comparison to non-holiday weeks. ${ }^{17}$ For 12 categories, the price change frequency for the holiday period 
is less than for the non-holiday period by more than 10 percent, and for 10 categories the difference exceeds 15 percent, with the maximum difference of 36 percent. Moreover, for 12 of the 16 cases, the difference is statistically significant. When aggregated over all categories, we find that price change activity drops by $12 \%$ during the holiday weeks in comparison to non-holiday weeks (with a statistical significance of 1 percent). Thus, the first test of our hypothesis shows that nominal prices tend to be relatively more rigid during holiday periods in comparison to non-holiday periods.

\section{Retailer's promotional activity}

We now consider the possibility that the retailer may emphasize greater promotional activity instead of price changes during the holiday period. We define promotions as any combination of in-store display, bonus buy, "on sale" promotion, manager's special, etc., and newspaper advertisement; because almost always these types of promotional activities are accompanied by a temporary price reduction. Dominick's database contains information on product-specific promotions in a form of dummy variables.

\section{Insert Table 3 about here}

The number of promotions per week is listed in Table 3, by category, and by holiday versus non-holiday periods. For 11 categories, the average number of weekly promotions during the non-holiday period is higher in comparison to the holiday period and this holds even if we aggregate across all categories. Thus, we do not see an increase in promotional activity as we move from non-holiday to holiday period. To the contrary, we find that during holiday weeks promotional activity seems to decrease on average. 


\section{Frequency of wholesale price changes}

A possible explanation for the decrease in retail price change activity during the holiday period could be a decrease in the wholesale price change activity at the manufacturers' level. In order to assess this possibility, we calculated the average number of wholesale price changes that the retailer encounters per week, by category, during holiday and nonholiday periods and the results are reported in Table 4.

\section{Insert Table 4 about here}

We find that the wholesale price change activity overall declines only by $4 \%(t=-$ 3.22) on average during holiday periods in comparison to the rest of the year. However, the retail price change activity decreases by far more, $12 \%$ on average, as indicated by the figures in Table 2. Moreover, according to Table 4, there are statistically significant more frequent non-holiday wholesale price changes for only 8 categories, in contrast to 13 categories for the retail prices.

Further, in some categories the differences in the frequency of the retail and wholesale price changes are larger than the factor of $3=12 \% / 4 \%$. For example, in the cereals category we find that during holiday weeks the retail price change frequency drops by 34\% (Table 2) in comparison to non-holiday weeks. In contrast, the wholesale price change frequency in this category increases by 3\% (Table 4).

The differences are large also in the categories of laundry detergents $(-19 \%$ for the retail price, versus $0 \%$ for the wholesale price), refrigerated juice ( $-11 \%$ for the retail price, versus $0 \%$ for the wholesale price), bottled juice ( $-16 \%$ for the retail price, versus 
$-1 \%$ for the wholesale price), cheese ( $-6 \%$ for the retail price, versus $0 \%$ for the wholesale price), dish detergents ( $-5 \%$ for the retail price, versus $+1 \%$ for the wholesale price), analgesics ( $-15 \%$ for the retail price, versus $-5 \%$ for the wholesale price), toothpastes ( $-18 \%$ for the retail price, versus $-5 \%$ for the wholesale price), frozen entrees ( $-36 \%$ for the retail price, versus $-13 \%$ for the wholesale price), fabric softeners $(-23 \%$ for the retail price, versus $-10 \%$ for the wholesale price), paper towels ( $-23 \%$ for the retail price, versus $-10 \%$ for the wholesale price), and toilet tissue ( $-23 \%$ for the retail price, versus $-11 \%$ for the wholesale price).

Only in three categories we obtain the ratio of the two frequencies to be close to 1 or below 1 . These include the categories of crackers $(-14 \%$ for the retail price, versus $-15 \%$ for the wholesale price), frozen juices ( $-8 \%$ for the retail price, versus $-12 \%$ for the wholesale price), and soft drinks ( $-7 \%$ for the retail price, versus $-9 \%$ for the wholesale price). These findings suggest that most of the decrease in retail price change activity is unlikely to be driven by decreases in the number of wholesale price changes.

Price response to changes in costs

Price rigidity is perhaps better defined as a lack of response of prices to changes in costs or demand. We have found that the frequency of price changes decreases during holidays. To bolster this result, we demonstrate that the likelihood of a price change decreases during holidays, even if factors such as promotions and cost changes are accounted for. That is, we show that the decrease in price change activity during holidays is not driven by holiday-related changes in promotional or wholesale pricing activities. To assess the likelihood of a price change, a logistic regression model is estimated: 
(1) $\log \left[p_{t} /\left(1-p_{t}\right)\right]=\alpha+\beta_{1}$ Holiday $_{t}+\beta_{2}$ Promotion $_{t}+\beta_{3} \Delta w_{t}+\beta_{4}\left(\right.$ Holiday $\left._{t} \times \Delta w_{t}\right)+\varepsilon_{t}$

where $p_{t}$ denotes the probability of a price change during week $t$, "Holiday" and "Promotion" are dummy variables, and the variable " $\Delta w_{t}$ " measures the absolute value of the change in the wholesale price in a given period.

The "Holiday" dummy variable equals 1 if week $t$ belongs to the six-week holiday period from Thanksgiving to Christmas and 0 otherwise. If prices are more rigid during holiday periods, then the likelihood of a price change will be lower during holiday periods, and the coefficient on the "Holiday" dummy variable will be negative $\left(\beta_{1}<0\right)$.

Dominick's data also include a dummy variable if a product on a given week was promoted, that is, was "on sale" or perhaps it was sold as a "bonus buy," etc. Because our focus is on the likelihood of a price change, we need to take into account any promotional price changes of this sort because it likely affects the probability of a price change. Thus, the variable "Promotion, is a dummy variable and it equals 1 if during week $t$ the product is promoted and 0 otherwise. We expect that when there is a promotion, there is a greater likelihood of a price change, ceteris paribus $\left(\beta_{2}>0\right)$.

The variable $\Delta w_{t}$ is computed as the absolute value of the first difference in the wholesale price. That is, $\Delta w_{t}=\left|w_{t}-w_{t-1}\right|$, where $w_{t}$ denotes the wholesale price. The goal of its inclusion is to capture the effect of a cost change on the retail price. Incorporating this measure in the model enables us to account for the possibility that changes in retail prices may be driven by changes in the wholesale prices, in addition to the effect of changes in the holiday period demand captured by the holiday dummy. We expect that the probability of a price change is larger, the larger the cost change, ceteris paribus $\left(\beta_{3}>0\right)$. 
Finally, the econometric model we estimate also includes the interaction term "Holiday ${ }_{t} \times \Delta w_{t}$ " which can have a positive or negative effect depending on whether or not the cost pass-through effect is strong enough to diminish the rigidity of the retail prices during holiday periods. Note that $\beta_{1}<0$ means that for a given $\Delta w_{t}$ the probability of a price change is higher during the non-holiday periods in comparison to the holiday periods. On the other hand, $\beta_{3}>0$ means that as $\Delta w_{t}$ increases, the probability of a price change increases as well, regardless of the period.

Now, because $\beta_{1}<0$ and $\beta_{3}>0$, a positive $\beta_{4}$ together with a negative $\beta_{1}$ (as illustrated in Figure 1 for the Frozen Entrees' category, and as found also for 9 other categories including analgesics, bottled juices, canned soup, frozen juices, refrigerated juice, soft drinks, canned fish, toothpastes and toilet tissues; See Table 5), indicates that the probability of price change is smaller for holidays, but the difference in the probability of a price change is driven more by small cost changes than by large cost changes. In other words, we are less likely to observe a pass-through of a cost change during holidays, especially when the cost change is small.

A negative $\beta_{4}$ together with a negative $\beta_{1}$ (as is the case, for example, for the laundry detergents' category; see Table 5), indicates that the probability of a price change is smaller for holidays, but the difference in the probability of a price change is driven more by large cost changes than by small cost changes. In other words, we are less likely to observe a pass-through of a cost change during holidays, especially when the cost change is large.

To summarize, a positive $\beta_{4}$ would mean that the effect of a given $\Delta w_{t}$ is magnified, yielding a larger gap between the holiday and non-holiday price change probabilities for "small" $\Delta w_{t}$, and smaller gap between these probabilities as $\Delta w_{t}$ becomes larger and 
larger. A negative $\beta_{4}$, on the other hand, would mean that as $\Delta w_{t}$ becomes larger and larger, the probabilities of a price change during the holiday and non-holiday periods diverge.

\section{Insert Table 5 about here}

We estimate the model for each product category using the method of maximum likelihood. The results are reported in Table 5. The figures in the first column are of particular interest. The estimated coefficients on the "Holiday" dummy variable are all negative, except for two categories, dish detergents and snack crackers, where the estimated coefficients are positive (the former statistically not significant but the latter statistically significant). Of the 16 categories with negative coefficients, for 15 of the categories the coefficients are statistically significant, all the $1 \%$ significance level, and the only statistically insignificant estimate is obtained for the category of soft drinks. These findings suggest that ceteris paribus, the likelihood of a price change is lower during the holiday period.

The estimated coefficients on the "Promotion" variable are all positive and statistically significant at 1 percent in each category. Thus, the presence of promotional activity tends to increase the odds ratio in favor of a price change, as expected.

The coefficients of the variable $\Delta w_{t}$ are all positive and statistically significant at 1 percent in each category. This implies that the larger the absolute value of the cost change, the higher the odds ratio in favor of a price change in response to the cost change.

Finally, the estimated coefficient on the interaction term "Holiday ${ }_{t} \times \Delta w_{t}$ is positive 
for 14 of the 18 categories. In 11 of the 14 cases, the coefficient is statistically significant. Of the four negative coefficients, two are statistically significant (for the categories of dish detergents and laundry detergents) and two are statistically insignificant (for the categories of cheeses and crackers). The finding of the positive coefficient on the interaction term in 11 categories suggests that in these categories the pass-through effect is strong enough to dampen the extent of holiday price rigidity.

We shall emphasize the meaning of the positive coefficient on the $\Delta w_{t}$ variable and the variation between the holiday and non-holiday periods. First, the positive coefficient of the variable $\Delta w_{t}$ suggests that the larger the cost change, the more likely is the price change. Or, reversing the argument, the smaller the cost change, the less likely is the price change. In other words, "small" price changers are less likely to be passed through. This finding seems to hold during both, holidays and non-holidays. This is shown in Figure 1 for cost changes from $-\$ 0.50$ to $+\$ 0.50$ for the category of Frozen Entrees.

Insert Figure 1 about here

Second, Figure 1 also shows that the probability of a price change is systematically lower during the holiday period in comparison to the non-holiday period. That is particularly true for "small" cost changes. As the absolute value of the cost change increases, the difference between the holiday and non-holiday periods slowly disappears. In other words, small cost changes are less likely to be passed-through than large price changes, and that is particularly true during the holiday period.

Third, Figure 1 indicates that the gap between the price change probabilities during the holiday and non-holiday periods decrease as the absolute value of the size of the cost 
change increases, because of the positive $\beta_{4}$ coefficient. That is, the slope of the plot for the holiday period is steeper in comparison to the non-holiday period. This implies that the main difference between the holiday and non-holiday periods is for small cost changes. As the size of the cost change increases to either direction, the probability of a price change during the holiday and non-holiday periods is essentially the same.

These three observations are consistent with the idea that the cost of a price change plays an important role in determining the extent of the price rigidity during holiday periods. We conclude, therefore, that a price change probability decreases during the holiday period, even when we account for holiday-related demand shifts, changes in manufacturer's wholesale prices, and the promotion activities. This is what the menu cost model predicts: when it is costly to change price (in our case, during the holiday periods), the likelihood of price changes is lower. Further, the higher price adjustment cost during the holiday period seems to reduce the probability of a pass-through of cost changes but only for small cost changes, which is consistent with the menu cost theory. When the cost changes are large, then we find no significant difference between the holiday and nonholiday periods. ${ }^{18}$

\section{Price response to changes in impact-adjusted costs}

An alternative way of assessing the effect of wholesale prices on retail prices is by capturing the impact a given wholesale price change has on the bottom line, and argue that a given cost change will have a greater effect on prices, the greater is the impact of the cost change on the seller's profits. With this in mind, we construct a variable "Impact ${ }_{t}$ " which measures the potential impact a given cost change might have on the retailer's profits, and estimate the following model: 
(2) $\log \left[p_{t} /\left(1-p_{t}\right)\right]=\alpha+\beta_{1}$ Holiday $_{t}+\beta_{2}$ Promotion $_{t}+\beta_{3}$ Impact $_{t}+\gamma_{i} d_{j}+\varepsilon_{t}$

The variables $d_{j}$ are manufacturer specific dummy variables which are used to account for individual manufacturers' effect on their products' retail prices through own company channels that may not be captured by the "Promotion" variable. Also, some manufacturers may be more important for the retailer due to higher profitability, greater support or slotting allowances and therefore, may be treated differently by the retailer. Based on a log-likelihood test using the Schwartz Criterion to reflect the number of terms and the number of observations, we find that these dummies are necessary. ${ }^{19}$

To assess the impact of a cost change on profit, we assume that the retailer can do one of two things in response to a cost change: (i) it can maintain the current price (i.e., do nothing), or (ii) it can pass through the entire cost change. ${ }^{20}$ We define the impact of a cost change as the difference in the expected profit between passing through the change and doing nothing. That is, the variable "Impact ${ }_{t}$ " is an estimate of the profit that would be earned if the price were changed by fully passing through the cost change minus the profit that would be earned if the price were not changed. As shown below, the way we construct this variable, it explicitly captures not only the changes in wholesale prices, but also changes in demand which often occur during the holiday periods. We expect that the greater the likely impact of a wholesale price change, the greater the likelihood of the price change $\left(\beta_{3}>0\right)$.

To construct the impact variable, we first estimate the profit when managers maintain the current price and no price change is undertaken in response to a cost change. This is estimated as the new per-unit profit margin times the number of units sold in the 
previous week. We use the prior week's sales volume because given that there is no price change, ceteris paribus, expected unit sales would not change either:

(3) $\quad \pi_{\text {do nothing }}=\left(p_{t-1}-w_{t}\right) m_{t-1}$

where $p_{t-1}$ denotes the price in prior period, $w_{t}$ denotes the new wholesale price, and $m_{t-1}$ denotes units sold in prior week.

Second, we estimate the profit when the entire cost change is passed through. If prices adjust in response to a cost change, the expected profit is given by

(4) $\pi_{\text {change price }}=\left[p_{t-1}+\left(w_{t}-w_{t-1}\right)-w_{t}\right] *\left[m_{t-1}+\left(\left(w_{t}-w_{t-1}\right) / p_{t-1}\right) * E * m_{t-1}\right]$

where the term in the first brackets is the old price plus adjustment minus the new cost, the term in the second brackets is the previous number of units sold plus the expected change in units sold due to price change, and $E$ denotes the average price elasticity.

The elasticity measures come from Hoch, et al. (1995) who use the same data to estimate individual product category demand elasticity. The price elasticity model fit the data quite well; $R^{2}$ ranges from 0.76 to 0.94 . Errors in the elasticity measure do not affect our results because they are absorbed in the error term (Greene, 1997).

Combining the terms and simplifying, the impact of a cost change becomes:

$$
\begin{aligned}
\text { Impact }_{t} & =\pi_{\text {change price }}-\pi_{\text {do nothing }} \\
& =m_{t-1}\left[\left(w_{t}-w_{t-1}\right)+\left(p_{t-1}-w_{t-1}\right)\left(\left(w_{t}-w_{t-1}\right) / p_{t-1}\right) * E\right] .
\end{aligned}
$$


We estimate the model for each product category using the method of maximum likelihood. The estimation results are reported in Table 6. The figures in the first column are of particular interest. The estimated coefficients on the "Holiday" dummy variable are all negative, except two categories, dish detergents and tooth pastes, where the estimated coefficients are positive but not statistically significant. Of the 16 categories with negative coefficients, for 13 of the categories the coefficients are statistically significant. These findings confirm that the likelihood of a price change is lower during holidays.

\section{Insert Table 6 about here}

The estimated coefficients on the "Promotion" variable are all positive and statistically significant at 1 percent in each category. Thus, manufacturers’ promotional activity tends to increase the odds ratio in favor of a price change. Also, the estimated coefficients of the "Impact" of cost change variable are all positive and statistically significant at 1 percent in each category. The larger the impact of a cost change on the profit, the higher the odds ratio in favor of a price change in response to a cost change. Finally, the manufacturer dummies are statistically significant in all categories, indicating that there is a manufacturer-specific variation in the retail price rigidity across holiday/non-holiday periods. ${ }^{21}$

Thus, we conclude that the likelihood of a price change decreases during the holiday periods, even after accounting for the holiday-related demand shifts, changes in manufacturer wholesale pricing activity, and the promotional efforts. 
We have also considered the possibility that the cost change pass-through might be asymmetric. To test for asymmetric price adjustment, we have estimated two models:

$$
\log \left[p_{t} /\left(1-p_{t}\right)\right]=\alpha+\beta_{1} \text { Holiday }_{t}+\beta_{2} \text { Promotion }_{t}+\beta_{3} \Delta w_{t}^{+}+\beta_{4}\left(\text { Holiday }_{t} \times \Delta w_{t}^{+}\right)+\varepsilon_{t}
$$

and

$$
\log \left[p_{t} /\left(1-p_{t}\right)\right]=\alpha+\beta_{1} \text { Holiday }_{t}+\beta_{2} \text { Promotion }_{t}+\beta_{3} \Delta w_{t}^{-}+\beta_{4}\left(\text { Holiday }_{t} \times \Delta w_{t}^{-}\right)+\varepsilon_{t} \text {, }
$$

where $\Delta w_{t}^{+}$and $\Delta w_{t}^{-}$denote cost increases and cost decreases, respectively.

The findings, which are discussed in the supplementary appendix (available upon request), suggest that the asymmetry is quite weak. For example, consider Figure 1, which displays the estimated probabilities of a price change for wholesale price changes $\Delta w_{t}$, from $-\$ 0.50$ to $+\$ 0.50$ for the category of Frozen Entrees. As the figure indicates, the probability of a price decrease in response to a cost decrease is slightly higher than the probability of a price increase in response to a cost increase of the same size. In other words, there seems to be a slight asymmetry towards more price decreases than increases for a given wholesale price change. According to Figure 1, this finding seems to hold primarily for the holiday period. ${ }^{22}$

A recent study by Chevalier, et al. (2003) uses the same Dominick's dataset and finds that during holidays, which they describe as periods of peak demand, prices are often lower than in non-holiday periods, which is counter to the standard textbook model. An interesting question that arises concerns the consistency of our findings with theirs. Our menu cost explanation does not make predictions about differences between price 
increases and decreases. In principle, the menu cost is the same whether the price increases or decreases. If we find a difference in the frequency of price increases and decreases, therefore, it must be driven by a difference in the benefit the price increases and decreases bring about, because their costs, i.e. the menu costs, are the same.

In Table 7 we report the average frequency of price increases and decreases per week during the holiday and non-holiday periods. The figures in the table indicate that there are less frequent price increases and also less frequent price decreases during the holiday periods in comparison to the non-holiday periods. For example, for 15 (5 statistically significant) of the 18 categories, there are fewer price increases during holidays in comparison to non-holidays. Similarly, for 15 (6 statistically significant) of the 18 categories, there are fewer price decreases during holidays in comparison to nonholidays. Thus, overall, we find that in comparison to non-holiday periods, during holiday periods there are fewer price increases and fewer price decreases.

\section{Insert Table 7 about here}

Next, compare the frequency of price increases to the frequency of price decreases for a given period (holiday or non-holiday). According to Table 7, during the 44-week non-holiday period, in 16 of the 18 categories the frequency of price increases exceeds the frequency of the price decreases. ${ }^{23}$ However, during the 6-week holiday period, the frequency of price increases is higher than the frequency of price decreases for only 9

categories. ${ }^{24}$ In other words, we find that during the holiday periods, there is an increase in the relative frequency of price decreases in comparison to the non-holiday periods, which is consistent with the findings reported by Chevalier, et al. (2003).

As a final analysis, we compare the frequency of price increases and decreases to the 
frequency of cost increases and decreases, in order to see whether or not the reduced frequency of the retail price increases and decreases during the holiday periods in comparison to non-holiday periods is driven by a reduced frequency of the wholesale price increases and decreases.

The frequencies of the cost (i.e., the wholesale price) increases and decreases during holidays and non-holidays are reported in Table 8. According to the figures in the table, in 14 categories there are fewer cost increases during the holiday weeks in comparison to non-holiday weeks. For the retail prices (Table 7) that was the case in 15 categories.

However, a comparison of the holiday/non-holiday frequency differences between the price and cost series suggests that the wholesale price behavior is unlikely to explain the retail price behavior for two reasons. First, when we consider all 18 product categories combined (see the rows labeled "Total" on the left hand side of Tables 7 and 8), then we find that the retail price increase frequency during the holiday periods drops by 14 percent in comparison to the non-holiday periods (Table 7). In contrast, the corresponding wholesale price increase frequency during the holiday periods drops only by 4 percent in comparison to the non-holiday periods (Table 8). In other words, the wholesale price behavior can "explain" less than a third of the retail price behavior.

Second, this finding holds true for the majority of the individual product categories as well. That is, in the majority of the categories for which prices and costs increase less frequently during the holiday periods, the holiday/non-holiday period frequency gap is substantially bigger for the price series than the cost series. For example, in the analgesics category, the price increase frequency goes down by 14 percent during holidays in comparison to non-holidays. In contrast, the wholesale price increase frequency during holidays falls only by 2 percent. Substantial differences are found also for the categories of bottled juice (7 percent decrease versus 3 percent decrease), cereals 
(22 percent decrease vs. 28 percent increase), dish detergents (3 percent decrease vs. 4 percent increase), frozen entrees (35 percent decrease versus 7 percent decrease), fabric softeners (10 percent decrease versus 3 percent decrease), laundry detergents (26 percent decrease versus 5 percent increase), paper towels (19 percent decrease versus 3 percent decrease), canned fish (22 percent decrease versus 8 percent decrease), and toilet tissue (28 percent decrease versus 11 percent decrease). Even in the categories where the frequency of price increase during holidays is higher in comparison to non-holidays, we find no clear relationship between the frequency gaps found for prices and the frequency gaps found for costs.

\section{Insert Table 8 about here}

Consider next the price and cost decreases. When we consider all 18 product categories combined (see the rows labeled "Total" on the right hand side of Tables 7 and 8), then we find that the retail price decrease frequency during the holiday periods drops by 10 percent in comparison to the non-holiday periods (Table 7). In contrast, the corresponding wholesale price decrease frequency during the holiday periods drops only by 4 percent in comparison to the non-holiday periods (Table 8).

The finding holds true for the majority of the categories as well. For example, in the bottled juices category, the price decrease frequency goes down by 25 percent during holidays in comparison to non-holidays. In contrast, the wholesale price decrease frequency during holidays increases by 2 percent. Substantial differences are found also for the categories of analgesics (17 percent decrease versus 12 percent decrease), cereals (52 percent decrease vs. 41 percent decrease), cheeses (1 percent decrease vs. 13 percent increase), crackers (5 percent decrease vs. 6 percent increase), dish detergents (7 percent 
decrease vs. 3 percent decrease), frozen entrees (38 percent decrease versus 19 percent decrease), fabric softeners (37 percent decrease versus 18 percent decrease), laundry detergents (12 percent decrease versus 5 percent decrease), paper towels (28 percent decrease versus 19 percent decrease), toothpaste (38 percent decrease versus 9 percent decrease), and toilet tissue (28 percent decrease versus 11 percent decrease). Similar to the case of price increases, we find no clear relationship between the frequency gaps found for prices and the frequency gaps found for costs even in the categories where price decrease frequency during holidays is higher in comparison to the non-holidays.

In sum, we find that during the holiday periods there is a decrease in the overall frequency of price changes, and this holds true for both price increases and decreases. However, among the price changes that are made during holiday periods, there are more

decreases than increases. ${ }^{25}$ Moreover, wholesale price changes can at best offer only a partial explanation.

\section{RULING-OUT OTHER SOURCES OF PRICE RIGIDITY}

In this section we briefly discuss alternative explanations for the holiday price rigidity by going through a list of the existing theories as provided by Blinder, et al. (1998), and discuss their potential relevance in explaining the increased price rigidity during holidays. It turns out that the unique nature of our cost and price data enables us to rule out most of the alternative theories. This is because many traditional explanations of the variation in price rigidity rely on variations in industrial structure, market organization, the nature of long-term relationships, contractual arrangements, or product quality. In our case, however, these and many other aspects of the market environment do not vary between holiday and non-holiday weeks. 
Theories based on the nature of costs

Clearly our cost of price adjustment explanation and the cost pass-through analyses we conducted above, fall in this category. However, other cost-based theories are not likely to be relevant in the context of our data because they require a variation between holiday and non-holiday periods. For example, theories of cost based pricing with lags (Gordon 1981, Blanchard 1983) do not seem to apply in our setting. There is little reason to believe that cost changes should pass-through more slowly through the channels during holidays in comparison to the rest of the year, without relying on our cost of price adjustment explanation.

The only cost-based theory that could apply to holiday/non-holiday differences is related to inventories. There is some evidence that inventories are used to smooth the variability of production (Fair, 1989; Krane and Braun, 1991; Carpenter and Levy, 1998). While we do not know whether the supermarket chain we study increases inventories in anticipation of the holidays, we do know that: (i) stores keep no inventory in a back room - all excess inventory which does not fit on the shelf is held at a central warehouse facility; and (ii) planograms do not get altered for the holidays. The store is generally stocked to capacity and cannot be expanded. Further, we do know that inventory levels vary across categories. It is this last point that suggests that inventories are unlikely to drive the holiday period price stickiness. In categories such as frozen juice and cereal, this retailer keeps one week of inventory (on average, throughout the year) while in other categories there is much more inventory (Müller, 1996). Yet the price stickiness we see does not vary systematically by inventory levels across categories. In Müller (1998) prices are stickiest for the orange juice products—precisely the products for which there 
are the least amount of inventory, which is counter to the inventory theory.

Theories based on the nature of contracts

Contracts between various channel participants in this industry, where they exist, are unlikely to vary between holiday and non-holiday periods regardless of whether they are implicit or explicit. The relationships between these channel participants are usually long-term in nature and written contracts cover long periods of time. These contracts may include specific terms and requirements during holidays on such issues as feature and display, and possibly price level (although only in broad terms, given the legal restrictions on resale price maintenance in the US). As far as we know, however, there are no implicit or explicit contracts that restrict the retailer's ability to change prices during holiday or non-holiday periods. Thus, we do not think contracts, either explicit or implicit, are likely to be the cause of the variation in price rigidity between holiday and non-holiday periods.

The other theory Blinder, et al. (1998) suggest in this area is guaranteed price protection. If a firm guarantees its customers that it will retroactively apply all discounts that may appear within a specified time period after a purchase, the firm may have a strong incentive to not cut prices, leading to price rigidity. This kind of pricing practice is often observed in some consumer durable goods markets (for example, in the computer and consumer electronics industry), but is not used in the retail supermarket industry.

\section{Theories based on the nature of market interactions}

Clearly, holiday periods are too short to exhibit large-scale changes in the market 
structure of the supermarket industry. Thus, theories that rely on variation in the market structure do not seem to apply in this setting.

The theories of oligopolistic price wars during booms (Rotemberg and Saloner, 1986) may have some relevance here because at the manufacturer level, some markets may be characterized as oligopolistic. To the degree that demand increases during holiday periods, perhaps holidays could share common features with booms, as suggested by Chevalier, et al. (2003). But because holidays last such short periods, we do not believe they really qualify as booms in economic parlance. Even if we were to identify the holiday weeks as booms, this theory would predict that prices should be less rigid during holiday periods, as there are gains to defection, which is counter to what we find. Therefore, this theory cannot explain our findings on holiday price rigidity.

The theory of coordination failure (Ball and Romer, 1991) could explain greater price rigidity during holidays. In the case of a cost increase that affects several competing supermarkets, each individual supermarket may be reluctant to be the first to increase prices out of fear that others will not follow. Without a price leader to coordinate price changes, a lack of coordination may lead to price stickiness. In our case, the question is whether price coordination between our chain and its competitors may be more difficult during holidays. One possibility is that the supermarket chain we study, which we know employs a cadre of price checkers who go to the competitors' stores to check prices, may use these price checkers to run the store during the holiday instead of checking and monitoring competitors' prices. If so, the coordination mechanism would certainly be weaker during the holidays, leading to greater price rigidity. In this case, the cost of price adjustment argument is extended to explain coordination failure. To that end, this suggests that coordination failure and costs of price adjustment may be related in that coordination requires the kinds of resources that make up the costs of changing prices. 
We can also rule out two other theories discussed by Blinder, et al. (1998) under this category. The first is changes in macroeconomic policy, and the second is hierarchical structure of large firms. It is unlikely that these two would vary between holiday and nonholiday periods.

Theories based on imperfect information

Imperfect information theories such as judging quality by price (Stiglitz, 1987) seem less appropriate for the retail supermarket setting. Most of the grocery items are frequently purchased items and therefore the public is familiar with their quality prior to purchase. Further, it is not clear why these price/quality effects would vary between holiday/nonholiday periods.

Theories based on the nature of demand

What about non-price adjustment mechanisms? Carlton (1989), among others, has suggested that markets may use non-price adjustment mechanisms, such as product quality or service quality, to clear. According to this explanation, instead of altering the price, firms may choose to alter the products’ quality or service quality, in order to accommodate changes in production costs or changes in demand.

At Dominick's, product quality is unlikely to vary between holiday and non-holiday periods because the vast majority of the products purchased during the holiday and nonholiday periods are the same. The main difference is in the quantity purchased. Also, as demonstrated above, production costs (wholesale prices) do not change radically between holiday and non-holiday periods, thus there may not be enough cost-based reasons to 
alter pricing activity. Chevalier, et al (2003) also find that changes in wholesale prices at this chain are “... small not only in absolute terms, but also in relation to retail margin changes” (p. 30).

In our case, because during holiday periods demand increases but prices are relatively rigid, we need to consider the possibility that perhaps there are non-price adjustments that increase the value of the products sold. Perhaps a case can be made that store appearance is more important during the holidays, which leads to installation of special holiday decorations. However, if the shopping experience is augmented during a high-demand period, then the theory would predict that prices should increase, which they do not.

To the extent that holiday shopping involves standing in long lines at cash registers (despite the store's management efforts), then perhaps we should view standing in line as a substitute for higher prices. In this case, we would conclude that the market clearing mechanism during the holiday period relies more heavily on waiting in line at the cash register (which in Carlton's framework could be termed “adjusting delivery time”), rather than price adjustment. The implication then would be that during holiday periods the nominal prices tend to be rigid, but this rigidity isn’t necessarily inefficient.

\section{Conclusion}

Our study builds on the literature studying variations in price rigidity across dimensions such as time, markets and products that has a long history in economics. These studies include Gordon (1983, 1990), Encaoua and Geroski (1984), Carlton (1986, 1989), Blinder (1991), Caplin and Leahy (1991), Hannan and Berger (1991), Geroski (1992), Neumark and Sharpe (1992), Carlton and Perloff (1994), Caucutt, et al. (1995), Hall, et 
al. (1997), and Slade $(1996,1998)$. We add directly to this literature by documenting an additional form of heterogeneity - variation in price rigidity across holiday and nonholiday periods.

Using large weekly scanner price and cost data from a large U.S retail chain, we find that prices are less likely to change during holiday periods in comparison to non-holiday periods even when we account for holiday-related demand shifts, changes in manufacturer's wholesale prices, and the promotion activities. This is what the menu cost model predicts: when it is costly to change price (in our case, during the holiday periods), the likelihood of price changes is lower. Further, the higher price adjustment cost during the holiday period seems to reduce the probability of a pass-through of cost changes but only for small cost changes, which is consistent with the menu cost theory. When the cost changes are large, then we find no significant difference between the holiday and nonholiday periods.

A unique aspect of our study is that our data form a natural experiment to study variation in price rigidity, as they enable us to rule out many common explanations offered for price rigidity (Carlton and Perloff, 1994). This is because the stores, market arrangements, industry concentration, nature of relationships, or other institutional features do not vary between holiday and non-holiday weeks.

Indeed, after surveying the existing price rigidity theories, we are able to rule out most of them as unable to explain the specific form of price rigidity we document here. We conclude that the holiday period price rigidity is best explained by higher price adjustment costs the retailers face during holidays. The anecdotic evidence we provide based on conversations with practitioners and pricing managers is consistent with this conclusion. Indeed, we have heard managers laugh at the thought of running price change experiments during holidays. For example, when attending a price consulting meeting at 
a large department store, the managers laughed at the suggestion of doing pricing experiments for measuring demand elasticity during holidays, stating that it would be "crazy" to think of doing that during holiday weeks. ${ }^{26}$

This study, thus, suggests a more important role for costs of price adjustment in determining the holiday pricing patterns than the existing literature recognizes. Based on our experience in the field, we suspect that the findings of holiday price rigidity would likely generalize to other multi-product retailers with posted prices such as department stores (Target, Sears, Best Buy, etc.). Nevertheless, it will be useful to go beyond these data to see whether the results generalize to other retail formats, markets, and industries. 


\section{ACKNOWLEDGEMENTS}

We are grateful to two anonymous referees for constructive comments and suggestions, and to the editors Tore Ellingsen and Alex Michaelides for guidance. We thank the participants of the NBER-CRIW Conference in Cambridge MA, and in particular, our discussant Walter Oi for his thoughtful comments, and Susanto Basu, Ernst Berndt, and Charles Hulten for suggestions. We also thank the Price Rigidity session participants at the American Economic Association Meeting, and especially the discussant John Carlson for useful comments and suggestions. Finally, we thank Dennis Carlton, Bob Chirinko, Joseph Deutsch, Hashem Dezhbakhsh, David Genesove, Akshay Rao, Avichai Snir, and the seminar participants at Emory University, Harvard University, and the University of Minnesota, for useful comments and discussions, and Rishi Modh for research assistant. Daniel Levy gratefully acknowledges the financial support from the Adar Foundation of the Economics Department at Bar-Ilan University. Haipeng (Allan) Chen acknowledges the Mays Research Fellowship for summer support. All authors contributed equally: we rotate co-authorship. The usual disclaimer applies. Address all correspondence to Daniel Levy, Department of Economics, Bar-Ilan University, Ramat-Gan 52900, Israel. Tel: + 972-3-531-8331, Fax: + 972-3-738-4034, Levyda@mail.biu.ac.il. 


\section{NOTES}

${ }^{1}$ Lach and Tsiddon (2007) and Levy, et al. (2008) offer a possible resolution of the small price change puzzle. See Cecchetti (1986), Caplin (1993), Sheshinski and Weiss (1993), and Wolman (2005), for surveys. See also Huang and Liu (2004), Zbaracki, et al. (2004, 2006), Eichenbaum, et al. (2008), Ellingsen, et al. (2005), Hoffmann and Kurz-Kim (2008), Rotemberg (1982, 1987), Basu (1995), Andersen (1994), Carlton (1986), Danziger (1983, 1999), Geroski (1992), Danziger and Kreiner (2002), Kashyap (1995), Bils and Klenow (2004), Slade (1996, 1998), Genesove (1999), and Ball and Romer (1991).

2 See Levy, et al. (2002) and Levy and Young (2004), and the studies cited therein.

${ }^{3}$ Müller, et al. (2006) use Dominick’s scanner price data to document significantly higher retail price rigidity for private label products in comparison to nationally branded products during the Christmas and Thanksgiving holiday periods relative to the rest of the year. They show that the finding cannot be explained by changes in holiday period promotional practices because it is found that private label promotions appear to diminish at least as much as national brands. The increased holiday period rigidity of private label products relative to national brands is only partially accounted for by increased rigidity of wholesale prices. After ruling out other potential explanations, they conclude that the higher private label price rigidity might be due to the increased emphasis on social consumption during holiday periods, raising the customers’ value of nationally branded products relative to the private labels. Müller, et al. (2007), using the same scanner price data, document periods of rigidity in product additions and deletions during holidays: new products are less likely to be introduced, and existing products are less likely to be 
discontinued during holiday periods than throughout the rest of the year. They argue that this is due to higher costs of undertaking these kinds of product assortment activities during holiday periods, a type of adjustment cost.

${ }^{4}$ Warner and Barsky (1995) also report that in the retail establishments they study, the sale prices are often planned in advance of the holidays. This is confirmed by a pricing consultant: "... large retailers set prices and promotions' schedules at least 2-3 months in advance. Thus, any holiday price promotions (they use discounts, direct mail coupons, and "bounce-backs" which are coupons for future purchases given at the cash register) are designed and decided by August, even though roll-out is not until November."

${ }^{5}$ Dutta, et al. (1999) find that labor input cost of price change preparation, implementation, and verification constitutes 79 percent costs of price adjustment at large US drugstore chains.

${ }^{6}$ An added difficulty in hiring college and university students is that they are let out for the holiday season around the 2nd week of December, making it difficult to properly train them as cashiers, etc. (R. DeGross and D. McClurkin, "Stores Starting Regular Holiday Hunt,” Atlanta Journal and Constitution, November 18, 2000, pages H1, H5).

${ }^{7}$ It turns out that the increased demand for temporary workers during holiday periods is not limited to the retail supermarket industry. According to L. Eaton ("Retailers Scramble for Holiday Help,” New York Times, Monday, September 27, 1999, p. A19), this is a more general and recurring phenomenon affecting many other types of retail as well as non-retail establishments including electronics stores and superstores, museums, bookstores, drugstores, high-priced boutiques and apparel chains, gift shops, furniture and home household goods, and jewelry stores. 
${ }^{8}$ For example, holiday-period tight labor markets force the retailers “... to become more generous with wages, bonuses" and some retail establishments are even forced to offer signing bonuses, as well as better discounts, flexible schedules, and bigger commissions, “... a practice already familiar to many area retailers,” (R. DeGross and D. McClurkin, “Stores Starting Regular Holiday Hunt,” Atlanta Journal and Constitution, November 18, 2000, page H1).

${ }^{9}$ But even if they were, the menu cost would be higher since the firm now pays overtime. Also, changing prices require more specialized skills and tasks than many other activities (Levy, et al., 1997, 1998). According to Robert Venable, the number of people a store will trust to change prices is limited, so it is unlikely that stores would assign this task to new, temporary, less skilled, or untrained employees.

${ }^{10}$ The data are available through the University of Chicago's marketing department web page at the address www.gsb.uchicago.edu/research/mkt/MarketingHomePage.html.

${ }^{11}$ Dominick's data actually include products in 29 categories but for many products the price/cost data are missing because they were not always recorded, especially for some critical holiday weeks.

${ }^{12}$ During the period in which the data were collected, pricing experiments were conducted at some stores within the chain. For the present analysis we use only data from control stores to avoid confounding effects.

${ }^{13}$ We also analyzed the data for the six mid-price stores only. We find that all the results reported in this paper for the 9 stores also hold for the six mid-price stores. Therefore, to save space we do not report these results in the paper. However, they were included in the previous version of the manuscript and are available upon request. 
${ }^{14}$ We note that coupon data is missing. However, coupons are offered by the manufacturer and not the retailer and thus do not reflect a retailer's pricing decisions. Furthermore, only a small portion of customers (less than 2\%, according to CMS' Coupon Trend Report, 1994) redeems the coupon when it is available. By contrast, temporary price discounts are offered by the retailer and affect all sales. As a result, the omission of coupon data is not felt to be a major limitation.

15 Thus, the wholesale costs do not correspond exactly to the replacement cost. Instead we have the average acquisition cost of the items in inventory. Instead we have the average acquisition cost (ACC) of the items in inventory. So the supermarket chain sets retail prices for the next week and also determines AAC at the end of each week, $t$, according to the formula

$$
\text { AAC }(t+1)=(\text { Inventory bought in } t) \text { Price paid }(t)+(\text { Inventory, end of } t \text {-l sales }(t))
$$
$\operatorname{AAC}(t)$

There are two main sources of discrepancy between replacement cost and AAC. The first is the familiar one of sluggish adjustment. A wholesale price cut today only gradually works itself into AAC as old, higher priced inventory is sold off. The second arises from the occasional practice of manufacturers to inform the buyer in advance of an impending temporary price reduction. This permits the buyer to completely deplete inventory and then "overstock" at the lower price. In this case AAC declines precipitously to the lower price and stays there until the large inventory acquired at that price runs off. Thus, the accounting cost shows the low price for some time after the replacement cost has gone back up. 
${ }^{16}$ We also considered other combinations of holiday weeks including two weeks before and after Christmas. Our results were similar for all of the alternative combinations we ran. We also considered including the Memorial Day, $4^{\text {th }}$ of July, and the Labor Day holidays, but we found that the holiday-period price rigidity results we report primarily hold for the Thanksgiving and the Christmas holidays.

${ }^{17}$ One exception, snack crackers category, might be explained by the fact that during the holiday period there is an increased consumption of snack crackers in social settings. This might increase the net value of frequent price changes for the products in this category during holiday weeks. We have no explanation for canned soups.

${ }^{18}$ We have also estimated another version of the econometric model given in (1). The model in (1) is a logistic regression. In the modification, the dependent variable was replaced with the size of the price change, $\Delta p_{t}$, while the independent variables were kept as in (1). The purpose of this analysis was to check whether or not the size of price changes during the holiday periods tend to be larger. Given the finding that prices during holidays tend to be more rigid, then perhaps when they do change, the change is larger. The results (are not reported to save space but included in the referee appendix available upon request), indicate that the answer to this question is mostly negative: the average size of the price change during holidays tends to be larger than during non-holidays only in 4 categories (3 of which are statistically significant).

19 The manufacturers' dummies enable us to capture any variation there may be across the different manufacturers. While there may also be a product-specific variation, an inclusion of the individual product dummies would exhaust all the degrees of freedom the data provide given the number of products. 
${ }^{20}$ This formulation assumes 100 percent pass-through rate when the retailer changes its price in response to a cost change. While this assumption may not hold for all items, the empirical results with respect to the holiday variable are not dependent on the rate of pass-through. Also, a recent study by Dutta, et al. (2002) reports a very fast (often within 1-2 weeks) and complete pass-through of cost changes onto prices. Our assumption, therefore, might be a reasonable approximation of what actually happens in this market. ${ }^{21}$ We do not report these coefficient estimates because of their large number in each regression equation.

${ }^{22}$ Levy, et al. (2008) study Dominick’s data set without separating the holiday and nonholiday periods and find what they term "asymmetric price adjustment in the small." Specifically, Levy, et al. find that in these data, there are more retail price increases than decreases for price changes of up to about 10 cents. The asymmetry disappears beyond that. They argue that the finding is consistent with a model in which shoppers are “rationally inattentive” to small price changes. Price setters take advantage of this inattention, making more frequent small price increases and decreases. Ray, et al. (2006) conduct a similar analysis of the wholesale price data in Dominick's dataset and report a similar finding. To explain the finding, Ray, et al. construct a model of channel of production with cost of price adjustment, and demonstrate that if the downstream price adjustment cost (i.e., the menu cost) is higher than the upstream price adjustment cost, then the wholesaler will have incentive to make more frequent small wholesale price increases than decreases, knowing that the small wholesale price increases will not be passed through on the final consumers because of the menu cost.

${ }^{23}$ In the remaining two categories the frequency of price decreases exceeds the frequency of price increases. 
${ }^{24}$ In the remaining 9 categories the frequency of price decreases exceeds the frequency of price increases.

${ }^{25}$ We have also explored the possibility of asymmetric retail price response to wholesale prices by focusing on the size of the retail price change. The model in (1) is a logistic regression. In the modification, the dependent variable was replaced with the size of the price change, $\Delta p_{t}$, and in addition, the independent variable $\Delta w_{t}$, which denotes the change in the wholesale price, was replaced with $\Delta w_{t}{ }_{t}^{+}$and $\Delta w_{t}{ }_{t}$, which denote the wholesale price increase and decrease, respectively. The results, not reported to save space (but included in the supplementary appendix available upon request), indicate that there is no evidence of asymmetry in the effect of wholesale price change on the size of price change, across the holiday/non-holiday periods.

${ }^{26}$ They clearly understood the value of price adjustment; they just were amazed at how little we knew about the price adjustment costs. 


\section{REFERENCES}

BALL, L, and MANKIW, N. G. (1994). Asymmetric price adjustment and economic fluctuations. Economic Journal, 104, 247-261.

BALL, L. and ROMER, D. (1991). Sticky prices as coordination failure. American Economic Review, 81, 539-552.

BARSKY, R., BERGEN, M., DUTTA, S., LEVY, D. (2003). What can the price gap between branded and private label products tell us about markups. In R. Feenstra and M. Shapiro (eds.), Scanner Data and Price Indexes. Chicago: University of Chicago Press, pp. 165-225.

BERGEN, M., LEVY, D., RAY, S., RUBIN, P. and ZELIGER, B. (2008). When little things mean a lot: on the inefficiency of item pricing laws. Journal of Law and Economics, forthcoming.

BLANCHARD, O. J. (1983). Price asynchronization and price level inertia. In R. Dornbusch and M. Simonsen (eds.), Inflation, Debt, and Indexation. Cambridge, MA: MIT Press.

BLINDER, A. (1991). Why are prices sticky? Preliminary results from an interview study. American Economic Review, 81, 89-96.

BLINDER, A., CANETTI, E.R.D., LEBOW, D.E., and RUDD, J.B. (1998). Asking About Prices: A New Approach to Understanding Price Stickiness. New York: Russell Sage Foundation.

CAPLIN, A. (1993). Individual inertia and aggregate dynamics. In E. Sheshinski and Y. Weiss (eds.), Optimal Pricing, Inflation, and the Cost of Price Adjustment. 
Cambridge, MA: The MIT Press, pp.19-45.

CARLTON, D. (1986). The rigidity of prices. American Economic Review, 76, 637-58.

CARLTON, D. (1989). The theory and the facts of how markets clear: is industrial organization valuable for understanding macroeconomics? In R. Schmalensee and R. D. Willig (eds.), Handbook of Industrial Organization, Volume 1. Amsterdam: North Holland, pp. 909-946.

CARLTON, D. and PERLOFF, J. (1994). Modern Industrial Organization. New York: Harper Collins.

CARPENTER, R. and LEVY, D. (1998). Seasonal cycles, business cycles, and the comovement of inventory investment and output. Journal of Money, Credit and Banking, 30, 331-346.

CECCHETTI, S. (1986). The frequency of price adjustment: a study of the newsstand prices of magazines. Journal of Econometrics, 31, 255-274.

CHEVALIER, J., KASHYAP, A., and ROSSI, P. (2003). Why don’t prices rise during peak demand periods? Evidence from scanner data. American Economic Review, 93, 15-37.

DANZIGER, L. (1983), Price adjustments with stochastic inflation. International Economic Review, 24, 699-707.

DANZIGER, L. (1999), A dynamic economy with costly price adjustment. American Economic Review, 89, 878-901.

DUTTA, S., BERGEN, M., LEVY, D., and VENABLE, R. (1999). Menu costs, posted prices, and multiproduct retailers. Journal of Money, Credit, and Banking, 31, 683703. 
DUTTA, S., BERGEN, M., and LEVY, D. (2002). Price flexibility in channels of distribution: evidence from scanner data. Journal of Economic Dynamics and Control, 26, 1845-1900.

FAIR, R. C. (1989). The production smoothing model is alive and well. Journal of Monetary Economics, 24, 353-370.

FISHER, T., and KONIECZNY, J. (2006). Inflation and costly price adjustment: a study of Canadian newspaper prices. Journal of Money, Credit and Banking, 38, 615-633.

GORDON, R. J. (1981). Output Fluctuations and Gradual Price Adjustment. Journal of Economic Literature, 19, 493-530.

GREENE, W. (1997). Econometric Analysis. New Jersey: Prentice Hall.

HOCH, S., MONTGOMERY, A.L., and ROSSI, P. (1995). Determinants of store-level price elasticity. Journal of Marketing Research, 32, 17-29.

KONIECZNY, J. and SKRZYPACZ, A. (2004). Search, costly price adjustment and the frequency of price changes: theory and evidence. Manuscript.

KRANE, S.D. and BRAUN, S.N. (1991). Production smoothing evidence from physicalproduct data. Journal of Political Economy, 99, 558-581.

LACH, S. and TSIDDON, D. (1996). Staggering and synchronization in price setting: evidence from multiproduct firms. American Economic Review, 86, 1175-1196.

LACH, S. and TSIDDON, D. (2007). Small price changes and menu costs. Managerial and Decision Economics, 28, 649-656.

LEVY, D., BERGEN, M., DUTTA, S. and VENABLE, R. (1997). The magnitude of menu costs: direct evidence from large U.S. supermarket chains. Quarterly Journal of Economics, 112, 791-825. 
LEVY, D., DUTTA, S., BERGEN, M. and VENABLE, R. (1998). Price adjustment at multiproduct retailers. Managerial and Decision Economics, 19, 81-120.

LEVY, D., DUTTA, S., BERGEN, M. and VENABLE, R. (2002). Heterogeneity in price rigidity: evidence from primary micro-level data. Journal of Money, Credit and Banking, 34, 197-220.

LEVY, D., CHEN, H., RAY, S., and BERGEN, M. (2008). Asymmetric price adjustment in the small. Journal of Monetary Economics, forthcoming.

MANKIW, N.G. (1985). Small menu costs and large business cycles: a macroeconomic model of monopoly. Quarterly Journal of Economics, 100, 529-539.

MÜLLER, G. (1996). The optimal inventory cycle when inventory affects demand. Unpublished manuscript.

MÜLLER, G. (1998). Asymmetric price responses to cost changes: evidence from the retail grocery industry. Ph.D. Thesis, GSB, University of Chicago.

MÜLLER, G., BERGEN, M., DUTTA, S. and LEVY, D. (2006). Private label price rigidity during holiday periods. Applied Economics Letters, 13, 57-62

MÜLLER, G., BERGEN, M., DUTTA, S. and LEVY, D. (2007). Non-price rigidity and cost of adjustment. Managerial and Decision Economics, 28, 817-832.

OLIVER, J. and FARRIS, P. (1989). Push and pull: a one-two punch for packaged products. Sloan Management Review, Fall, 53-61.

OWEN, A. and TRZEPACZ, D. (2002). Menu costs, firm strategy, and price rigidity. Economics Letters, 76, 345-349.

PASHIGIAN, P. and BOWEN, B. (1991). Why are products sold on sale? Explanations of pricing regularities. Quarterly Journal of Economics, 106, 1015-1038. 
RAY, S., CHEN, H., BERGEN, M., LEVY, D. (2006). Asymmetric wholesale pricing: theory and evidence. Marketing Science, 25, 131-154.

ROTEMBERG, J.J., and SALONER, G. (1986). A supergame-theoretic model of price wars during booms. American Economic Review, 76, 390-407.

SHESHINSKI, E. and WEISS, Y. (1993). Optimal Pricing, Inflation, and the Cost of Price Adjustment. Cambridge, MA: The MIT Press.

SLADE, M.E. (1998). Optimal pricing with costly adjustment: evidence from retailgrocery prices. Review of Economic Studies, 65, 87-107.

STIGLITZ, J.E. (1987). The causes and consequences of the dependence of quality on price. Journal of Economic Literature, 25, 1-48.

WARNER, E. and BARSKY, R. (1995). The timing and magnitude of retail store markdowns: evidence from weekends and holidays. Quarterly Journal of Economics, 110, 321-352.

ZBARACKI, M., RITSON, M., LEVY, D., DUTTA, S., and BERGEN, M. (2004). Managerial and customer costs of price adjustment: direct evidence from industrial markets. Review of Economics and Statistics, 86, 514-533.

ZBARACKI, M., BERGEN, M., and LEVY, D. (2006). The anatomy of a price cut: Discovering organizational sources of the costs of price adjustment. Bar-Ilan University Working Paper. 
TABLE 1

THE DATASET: PRODUCT CATEGORIES AND THE NUMBER OF PRODUCTS PER STORE

\begin{tabular}{clc}
\hline No. & Product Category & Number of Products \\
\hline 1 & Analgesics & 227 \\
2 & Bottled Juices & 263 \\
3 & Cereals & 290 \\
4 & Cheeses & 377 \\
5 & Crackers & 137 \\
6 & Canned Soups & 304 \\
7 & Dish Detergents & 181 \\
8 & Frozen Entrees & 551 \\
9 & Frozen Juices & 117 \\
10 & Fabric Softeners & 196 \\
11 & Laundry Detergents & 360 \\
12 & Paper Towels & 85 \\
13 & Refrigerated Juices & 112 \\
14 & Soft Drinks & 611 \\
15 & Snack Crackers & 228 \\
16 & Canned Fish & 168 \\
17 & Toothpastes & 255 \\
18 & Toilet Tissues & 70 \\
\hline
\end{tabular}

Notes: The data are sampled at weekly frequency, and cover the period from the week of September 14, 1989 to the week of May 8, 1997.

The data come from 6 mid-price and 3 low-price stores of Dominick's, all operating in the Chicago metro area. 
TABLE 2

AVERAGE NUMBER OF RETAIL PRICE CHANGES PER STORE PER WEEK DURING THE HOLIDAY AND NON-HOLIDAY PERIODS

\begin{tabular}{lcccc}
\hline Product Category & Non-Holiday & Holiday & \% Difference & $t$-statistic \\
\hline Analgesics & 12.38 & 10.47 & $-15 \%$ & $-1.59^{\mathrm{c}}$ \\
Bottled Juices & 26.21 & 22.10 & $-16 \%$ & $-1.72^{\mathrm{c}}$ \\
Cereals & 21.41 & 14.07 & $-34 \%$ & $-2.79^{\mathrm{a}}$ \\
Cheeses & 45.72 & 43.05 & $-6 \%$ & $-0.75^{\circ}$ \\
Crackers & 14.51 & 12.46 & $-14 \%$ & $-1.01^{\circ}$ \\
Canned Soups & 27.45 & 27.89 & $2 \%$ & 0.18 \\
Dish Detergents & 11.05 & 10.52 & $-5 \%$ & -0.47 \\
Frozen Entrees & 53.60 & 34.18 & $-36 \%$ & $-5.98^{\mathrm{a}}$ \\
Frozen Juices & 16.98 & 15.60 & $-8 \%$ & $-0.86^{\mathrm{a}}$ \\
Fabric Softeners & 10.36 & 8.01 & $-23 \%$ & $-2.16^{\mathrm{a}}$ \\
Laundry Detergents & 17.26 & 13.99 & $-19 \%$ & $-2.23^{\mathrm{a}}$ \\
Paper Towels & 7.15 & 5.49 & $-23 \%$ & $-2.12^{\mathrm{b}}$ \\
Refrigerated Juices & 18.40 & 16.42 & $-11 \%$ & $-1.61^{\mathrm{c}}$ \\
Soft Drinks & 117.83 & 109.84 & $-7 \%$ & $-1.53^{\mathrm{c}}$ \\
Snack Crackers & 24.07 & 31.07 & $29 \%$ & $2.21^{\mathrm{a}}$ \\
Canned Fish & 13.32 & 11.05 & $-17 \%$ & $-15.1^{\mathrm{a}}$ \\
Toothpastes & 18.8 & 15.5 & $-18 \%$ & $-1.33^{\mathrm{c}}$ \\
Toilet Tissues & 8.75 & 6.74 & $-23 \%$ & $-2.25^{\mathrm{a}}$ \\
\hline Total & 465.25 & 408.45 & $-12 \%$ & $-4.72^{\mathrm{a}}$ \\
\hline
\end{tabular}

Notes: Retail prices are the actual transaction prices, as recorded by the store scanners.

The prices are changed at the weekly frequency, which is standard retail food industry practice.

As the holiday period in each year, we define the week before Thanksgiving through the week of Christmas, a total of six week period. The remaining weeks are defined as non-holiday periods. Superscripts $a, b$, and $c$ indicate statistical significance at 1,5 , and 10 percents, respectively. 
TABLE 3

AVERAGE NUMBER OF PROMOTIONS PER STORE PER WEEK DURING THE HOLIDAY AND NON-HOLIDAY PERIODS

\begin{tabular}{lcccc}
\hline Product Category & Non-Holiday & Holiday & \% Difference & $t$-statistic \\
\hline Analgesics & 4.7 & 7.5 & $61 \%$ & $3.09^{\mathrm{a}}$ \\
Bottled Juices & 14.3 & 12.0 & $-16 \%$ & $-1.80^{\mathrm{b}}$ \\
Cereals & 11.8 & 7.0 & $-41 \%$ & $-4.38^{\mathrm{a}}$ \\
Cheeses & 18.2 & 20.5 & $13 \%$ & $0.91^{\mathrm{a}}$ \\
Crackers & 7.3 & 10.5 & $43 \%$ & $4.36^{\mathrm{a}}$ \\
Canned Soups & 9.8 & 17.0 & $73 \%$ & $1.62^{\mathrm{c}}$ \\
Dish Detergents & 5.7 & 5.0 & $-12 \%$ & -0.97 \\
Frozen Entrees & 28.5 & 12.5 & $-56 \%$ & $-4.68^{\mathrm{a}}$ \\
Frozen Juices & 9.2 & 9.2 & $0 \%$ & $0.00^{\mathrm{a}}$ \\
Fabric Softeners & 5.8 & 3.5 & $-40 \%$ & $-4.48^{\mathrm{a}}$ \\
Laundry Detergents & 11.7 & 7.0 & $-40 \%$ & $-7.32^{\mathrm{a}}$ \\
Paper Towels & 4.7 & 4.2 & $-11 \%$ & -1.29 \\
Refrigerated Juices & 10.8 & 8.5 & $-22 \%$ & $-2.96^{\mathrm{a}}$ \\
Soft Drinks & 67.7 & 60.3 & $-11 \%$ & $-2.00^{\mathrm{b}}$ \\
Snack Crackers & 9.8 & 17.8 & $81 \%$ & $2.14^{\mathrm{b}}$ \\
Canned Fish & 4.3 & 15.3 & $254 \%$ & $17.24^{\mathrm{a}}$ \\
Toothpastes & 14.0 & 9.3 & $-33 \%$ & $-3.27^{\mathrm{a}}$ \\
Toilet Tissues & 4.8 & 4.7 & $-3 \%$ & -0.33 \\
\hline Total & 243.2 & 231.8 & $-5 \%$ & $-1.30^{\mathrm{c}}$ \\
\hline
\end{tabular}

Notes: Promotions are defined as any combination of in-store display, bonus buy, "on sale", manager's special, etc., as well as newspaper advertisement.

Dominick's database contains information on product-specific promotions in a form of dummy variables. As the holiday period in each year, we define the week before Thanksgiving through the week of Christmas, a total of six week period. The remaining weeks are defined as non-holiday periods.

Superscripts $a, b$, and $c$ indicate statistical significance at 1,5 , and 10 percents, respectively. 
TABLE 4

AVERAGE NUMBER OF WHOLESALE PRICE (I.E. COST) CHANGES PER STORE PER WEEK DURING THE HOLIDAY AND NON-HOLIDAY PERIODS

\begin{tabular}{lcccc}
\hline Product Category & Non-Holiday & Holiday & \% Difference & $t$-statistic \\
\hline Analgesics & 32.02 & 30.26 & $-5 \%$ & -0.99 \\
Bottled Juices & 60.19 & 59.63 & $-1 \%$ & -0.21 \\
Cereals & 62.59 & 64.22 & $3 \%$ & 0.33 \\
Cheeses & 106.55 & 106.56 & $0 \%$ & 0.00 \\
Crackers & 18.81 & 15.90 & $-15 \%$ & $-1.29^{\mathrm{c}}$ \\
Canned Soups & 60.69 & 63.61 & $5 \%$ & 1.18 \\
Dish Detergents & 22.89 & 23.17 & $1 \%$ & 0.23 \\
Frozen Entrees & 101.52 & 88.56 & $-13 \%$ & $-2.58^{\mathrm{a}}$ \\
Frozen Juices & 35.31 & 31.22 & $-12 \%$ & $-2.59^{\mathrm{a}}$ \\
Fabric Softeners & 25.03 & 22.56 & $-10 \%$ & $-1.99^{\mathrm{b}}$ \\
Laundry Detergents & 40.08 & 40.24 & $0 \%$ & $0.09^{\mathrm{a}}$ \\
Paper Towels & 14.81 & 13.28 & $-10 \%$ & $-2.09^{\mathrm{b}}$ \\
Refrigerated Juices & 37.84 & 37.68 & $0 \%$ & -0.10 \\
Soft Drinks & 138.84 & 126.73 & $-9 \%$ & $-1.77^{\mathrm{c}}$ \\
Snack Crackers & 32.55 & 37.28 & $15 \%$ & 1.36 \\
Canned Fish & 24.54 & 21.94 & $-11 \%$ & $-5.18^{\mathrm{a}}$ \\
Toothpastes & 32.74 & 31.08 & $-5 \%$ & $-0.67^{\mathrm{a}}$ \\
Toilet Tissues & 16.43 & 14.56 & $-11 \%$ & $-2.54^{\mathrm{a}}$ \\
\hline Total & 863.00 & 828.48 & $-4 \%$ & $-3.22^{\mathrm{a}}$ \\
\hline
\end{tabular}

Notes: Wholesale price (i.e., the cost) series come from the chain's database. They are computed as a weighted average of the amount the retailer paid for its entire inventory held in a given week.

As the holiday period in each year, we define the week before Thanksgiving through the week of Christmas, a total of six week period. The remaining weeks are defined as non-holiday periods.

Superscripts $a, b$, and $c$ indicate statistical significance at 1,5 , and 10 percents, respectively. 
TABLE 5

PRICE RESPONSE TO CHANGES IN COSTS

\begin{tabular}{|l|c|c|c|c|c|c|c|c|}
\hline \multirow{2}{*}{ Product Category } & \multicolumn{2}{|c|}{ Holiday } & \multicolumn{2}{c|}{ Promotion } & \multicolumn{3}{c|}{$\Delta w_{t}$} & \multicolumn{2}{c|}{ Holiday $_{t} \times \Delta w_{t}$} \\
\cline { 2 - 8 } & Coefficient & $p$-value & Coefficient & $p$-value & Coefficient & $p$-value & Coefficient & $p$-value \\
\hline Analgesics & -0.2076 & $<.0001$ & 3.3025 & $<.0001$ & 1.5969 & $<.0001$ & 0.5439 & 0.0067 \\
\hline Bottled Juices & -0.2088 & $<.0001$ & 2.5918 & $<.0001$ & 5.9429 & $<.0001$ & 0.5217 & 0.0800 \\
\hline Cereals & -0.4589 & $<.0001$ & 3.5041 & $<.0001$ & 4.1344 & $<.0001$ & 0.2877 & 0.3503 \\
\hline Cheeses & -0.0900 & $<.0001$ & 3.3891 & $<.0001$ & 3.9915 & $<.0001$ & -0.1740 & 0.3996 \\
\hline Crackers & -0.2068 & $<.0001$ & 3.1233 & $<.0001$ & 8.3543 & $<.0001$ & -0.3869 & 0.4731 \\
\hline Canned Soup & -0.0523 & 0.0127 & 3.9375 & 0.0001 & 10.7405 & 0.0001 & 1.4035 & 0.0035 \\
\hline Dish Detergent & 0.0349 & 0.2657 & 3.9964 & $<.0001$ & 1.6800 & $<.0001$ & -3.1603 & $<.0001$ \\
\hline Frozen Entrees & -0.4122 & $<.0001$ & 3.7145 & $<.0001$ & 5.2531 & $<.0001$ & 0.5322 & 0.0015 \\
\hline Frozen Juices & -0.1100 & 0.0002 & 2.9009 & $<.0001$ & 9.2661 & $<.0001$ & 3.3939 & $<.0001$ \\
\hline Fabric Softeners & -0.2318 & $<.0001$ & 3.699 & $<.0001$ & 3.5911 & $<.0001$ & 0.0987 & 0.8406 \\
\hline Laundry Detergent & -0.1358 & $<.0001$ & 3.5938 & $<.0001$ & 0.9447 & $<.0001$ & -1.2446 & $<.0001$ \\
\hline Paper Towels & -0.3594 & $<.0001$ & 3.1716 & $<.0001$ & 5.8146 & $<.0001$ & 0.0365 & 0.6080 \\
\hline Refrigerated Juice & -0.1728 & $<.0001$ & 2.4115 & $<.0001$ & 3.5955 & $<.0001$ & 0.1891 & $<.0001$ \\
\hline Soft Drinks & -0.0021 & 0.8872 & 2.4479 & $<.0001$ & 4.3080 & $<.0001$ & 0.3004 & 0.0003 \\
\hline Snack Crackers & 0.2742 & $<.0001$ & 3.212 & $<.0001$ & 7.6415 & $<.0001$ & 1.0243 & 0.0180 \\
\hline Canned Fish & -0.3437 & $<.0001$ & 3.8533 & $<.0001$ & 8.2278 & $<.0001$ & 3.8414 & $<.0001$ \\
\hline Tooth Pastes & -0.1162 & $<.0001$ & 3.4971 & $<.0001$ & 3.3948 & $<.0001$ & 0.4838 & 0.0759 \\
\hline Toilet Tissues & -0.4379 & $<.0001$ & 2.2076 & $<.0001$ & 7.5574 & $<.0001$ & 1.8996 & $<.0001$ \\
\hline
\end{tabular}

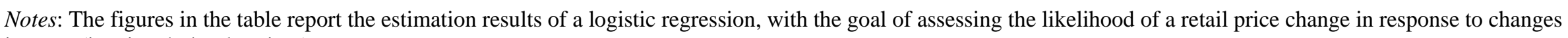
in costs (i.e., in wholesale prices).

The estimation uses the method of maximum likelihood.

The dependent variable is $\log \left[p_{t} /\left(1-p_{t}\right)\right]$.

The independent variables employed are defined as follows:

Holiday - dummy variable attaining value 1 during holiday week, 0 otherwise.

Promotion - dummy variable attaining value 1 if the product was promoted on a given week, 0 otherwise.

$\Delta w_{t}$ - the absolute value of the first difference in the wholesale price, measuring the cost change.

Holiday $_{t} \times \Delta w_{t}-$ interaction term. 
TABLE 6

PRICE RESPONSE TO CHANGES IN IMPACT-ADJUSTED COSTS

\begin{tabular}{lccc}
\hline Product Category & Holiday & Promotion & Impact \\
\hline Analgesics & $-0.1948^{\mathrm{b}}$ & $0.4918^{\mathrm{a}}$ & $0.5702^{\mathrm{a}}$ \\
Bottled Juices & $-0.3093^{\mathrm{a}}$ & $0.6431^{\mathrm{a}}$ & $0.1966^{\mathrm{a}}$ \\
Cereals & $-0.3671^{\mathrm{a}}$ & $1.2690^{\mathrm{a}}$ & $0.0764^{\mathrm{a}}$ \\
Cheeses & $-0.2279^{\mathrm{a}}$ & $1.3276^{\mathrm{a}}$ & $0.1182^{\mathrm{a}}$ \\
Crackers & $-0.2489^{\mathrm{a}}$ & $0.5518^{\mathrm{a}}$ & $0.2575^{\mathrm{a}}$ \\
Canned Soups & $-0.1008^{\mathrm{b}}$ & $1.5303^{\mathrm{a}}$ & $0.0065^{\mathrm{a}}$ \\
Dish Detergents & $0.0588^{\mathrm{a}}$ & $1.3866^{\mathrm{a}}$ & $0.1735^{\mathrm{a}}$ \\
Frozen Entrees & $-0.2192^{\mathrm{a}}$ & $1.7355^{\mathrm{a}}$ & $0.0912^{\mathrm{a}}$ \\
Frozen Juices & $-0.1545^{\mathrm{b}}$ & $1.8239^{\mathrm{a}}$ & $0.0763^{\mathrm{a}}$ \\
Fabric Softeners & $-0.1377^{\mathrm{a}}$ & $0.5439^{\mathrm{a}}$ & $0.4205^{\mathrm{a}}$ \\
Laundry Detergents & $-0.2513^{\mathrm{a}}$ & $0.7818^{\mathrm{a}}$ & $0.1855^{\mathrm{a}}$ \\
Paper Towels & $-0.4895^{\mathrm{a}}$ & $1.6889^{\mathrm{a}}$ & $0.0110^{\mathrm{a}}$ \\
Refrigerated Juices & $-0.2529^{\mathrm{a}}$ & $1.0781^{\mathrm{a}}$ & $0.0398^{\mathrm{a}}$ \\
Soft Drinks & $-0.0073^{\mathrm{a}}$ & $1.2724^{\mathrm{a}}$ & $0.0023^{\mathrm{a}}$ \\
Snack Crackers & $-0.0192^{\mathrm{a}}$ & $0.5519^{\mathrm{a}}$ & $0.3452^{\mathrm{a}}$ \\
Canned Fish & $-0.4166^{\mathrm{a}}$ & $0.9438^{\mathrm{a}}$ & $0.0004^{\mathrm{a}}$ \\
Toothpastes & $0.0228^{\mathrm{a}}$ & $1.3904^{\mathrm{a}}$ & $0.5414^{\mathrm{a}}$ \\
Toilet Tissues & $-0.5062^{\mathrm{a}}$ & $0.9611^{\mathrm{a}}$ & $0.0025^{\mathrm{a}}$ \\
\hline
\end{tabular}

Notes: The figures in the table report the estimation results of a logistic regression, with the goal of assessing the likelihood of a price change in response to changes in costs (i.e., in wholesale prices) taking into account the size of the impact of the cost change on the retailer's profit.

The estimation uses the method of maximum likelihood.

The dependent variable is $\log \left[p_{t} /\left(1-p_{t}\right)\right]$.

The independent variables employed are defined as follows:

Holiday - dummy variable attaining value 1 during holiday week, 0 otherwise.

Promotion - dummy variable attaining value 1 if the product was promoted on a given week, 0 otherwise.

Impact - estimate of the profit that would be earned if the price were changed by fully passing through the cost (i.e., the wholesale price) change minus the profit that would be earned if the price were not changed. The way the variable is constructed, it captures not only the changes in wholesale prices, but also changes in demand during the holiday periods.

The regression equation also includes manufacturer-specific dummy variables.

Superscripts $a, b$, and $c$ indicate statistical significance at 1,5 , and 10 percents, respectively. 
TABLE 7

ASYMMETRIC PRICE ADJUSTMENT: AVERAGE NUMBER OF RETAIL PRICE INCREASES AND RETAIL PRICE DECREASES PER STORE PER WEEK DURING THE HOLIDAY AND NON-HOLIDAY PERIODS

\begin{tabular}{|c|c|c|c|c|c|c|c|c|}
\hline \multirow[b]{2}{*}{ Product Category } & \multicolumn{4}{|c|}{ Price Increases } & \multicolumn{4}{|c|}{ Price Decreases } \\
\hline & Non-Holiday & Holiday & \% Difference & t-statistic & Non-Holiday & Holiday & \% Difference & $t$-statistic \\
\hline Analgesics & 7.33 & 6.28 & $-14 \%$ & -1.29 & 5.05 & 4.18 & $-17 \%$ & -0.97 \\
\hline Bottled Juices & 13.51 & 12.58 & $-7 \%$ & -0.58 & 12.70 & 9.51 & $-25 \%$ & $-1.98^{b}$ \\
\hline Cereals & 12.49 & 9.76 & $-22 \%$ & -1.23 & 8.92 & 4.31 & $-52 \%$ & $-4.27^{a}$ \\
\hline Cheeses & 23.91 & 21.38 & $-11 \%$ & -1.00 & 21.82 & 21.67 & $-1 \%$ & -0.05 \\
\hline Crackers & 7.61 & 5.24 & $-31 \%$ & $-1.98^{\mathrm{b}}$ & 6.90 & 7.22 & $5 \%$ & 0.18 \\
\hline Canned Soups & 14.96 & 15.05 & $1 \%$ & 0.06 & 12.49 & 12.84 & $3 \%$ & 0.20 \\
\hline Dish Detergents & 5.54 & 5.37 & $-3 \%$ & -0.21 & 5.52 & 5.15 & $-7 \%$ & -0.40 \\
\hline Frozen Entrees & 27.43 & 17.85 & $-35 \%$ & $-3.34^{\mathrm{a}}$ & 26.17 & 16.33 & $-38 \%$ & $-3.78^{a}$ \\
\hline Frozen Juices & 8.51 & 7.20 & $-15 \%$ & -1.16 & 8.47 & 8.40 & $-1 \%$ & -0.06 \\
\hline Fabric Softeners & 5.42 & 4.90 & $-10 \%$ & -0.68 & 4.94 & 3.10 & $-37 \%$ & $-3.14^{\mathrm{a}}$ \\
\hline Laundry Detergents & 8.71 & 6.43 & $-26 \%$ & $-3.15^{a}$ & 8.55 & 7.56 & $-12 \%$ & -0.85 \\
\hline Paper Towels & 3.49 & 2.84 & $-19 \%$ & -1.22 & 3.65 & 2.65 & $-28 \%$ & $-2.03^{\mathrm{b}}$ \\
\hline Refrigerated Juices & 9.13 & 7.19 & $-21 \%$ & $-2.37^{a}$ & 9.26 & 9.24 & $0 \%$ & -0.03 \\
\hline Soft Drinks & 59.26 & 52.61 & $-11 \%$ & -1.43 & 58.57 & 57.23 & $-2 \%$ & -0.32 \\
\hline Snack Crackers & 12.60 & 14.04 & $11 \%$ & 0.57 & 11.47 & 17.03 & $48 \%$ & $2.71^{\mathrm{a}}$ \\
\hline Canned Fish & 6.77 & 5.28 & $-22 \%$ & -1.17 & 6.55 & 5.77 & $-12 \%$ & -0.99 \\
\hline Toothpastes & 9.69 & 10.19 & $5 \%$ & 0.19 & 7.88 & 4.87 & $-38 \%$ & $-2.31^{a}$ \\
\hline Toilet Tissues & 4.49 & 3.25 & $-28 \%$ & $-2.08^{\mathrm{b}}$ & 4.25 & 3.49 & $-18 \%$ & -1.44 \\
\hline Total & 240.85 & 207.44 & $-14 \%$ & $-4.76^{a}$ & 223.16 & 200.55 & $-10 \%$ & $-3.31^{a}$ \\
\hline
\end{tabular}

Notes: Retail prices are the actual transaction prices, as recorded by the store scanners.

The prices are changed at the weekly frequency, which is standard retail food industry practice.

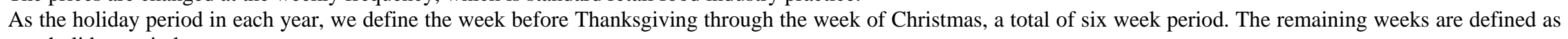
non-holiday periods.

Superscripts $a, b$, and $c$ indicate statistical significance at 1,5 , and 10 percents, respectively. 
TABLE 8

ASYMMETRIC COST ADJUSTMENT: AVERAGE NUMBER OF WHOLESALE PRICE INCREASES AND WHOLESALE PRICE DECREASES PER STORE PER WEEK DURING THE HOLIDAY AND NON-HOLIDAY PERIODS

\begin{tabular}{|c|c|c|c|c|c|c|c|c|}
\hline \multirow[b]{2}{*}{ Product Category } & \multicolumn{4}{|c|}{ Cost Increases } & \multicolumn{4}{|c|}{ Cost Decreases } \\
\hline & Non-Holiday & Holiday & \% Difference & $t$-statistic & Non-Holiday & Holiday & \% Difference & $t$-statistic \\
\hline Analgesics & 19.84 & 19.49 & $-2 \%$ & -0.28 & 12.18 & 10.77 & $-12 \%$ & $-1.56^{c}$ \\
\hline Bottled Juices & 33.86 & 32.80 & $-3 \%$ & -0.71 & 26.33 & 26.83 & $2 \%$ & 0.23 \\
\hline Cereals & 39.64 & 50.70 & $28 \%$ & $2.46^{\mathrm{a}}$ & 22.95 & 13.52 & -41 & $-8.09^{a}$ \\
\hline Cheeses & 57.30 & 50.71 & $-11 \%$ & $-1.76^{c}$ & 49.25 & 55.85 & $13 \%$ & 1.48 \\
\hline Crackers & 10.01 & 7.65 & $-24 \%$ & $-2.50^{a}$ & 8.80 & 8.26 & $-6 \%$ & -0.32 \\
\hline Canned Soups & 35.65 & 36.97 & $4 \%$ & 0.67 & 25.04 & 26.65 & $6 \%$ & 1.31 \\
\hline Dish Detergents & 12.66 & 13.22 & $4 \%$ & 0.48 & 10.22 & 9.95 & $-3 \%$ & -0.38 \\
\hline Frozen Entrees & 51.54 & 48.19 & $-7 \%$ & -1.12 & 49.98 & 40.37 & $-19 \%$ & $-2.70^{a}$ \\
\hline Frozen Juices & 17.92 & 13.89 & $-22 \%$ & $-4.22^{\mathrm{a}}$ & 17.39 & 17.33 & $0 \%$ & -0.05 \\
\hline Fabric Softeners & 13.36 & 12.98 & $-3 \%$ & -0.45 & 11.67 & 9.58 & $-18 \%$ & $-2.43^{a}$ \\
\hline Laundry Detergents & 21.87 & 22.94 & $5 \%$ & 0.98 & 18.22 & 17.29 & $-5 \%$ & -0.70 \\
\hline Paper Towels & 7.76 & 7.56 & $-3 \%$ & -0.36 & 7.05 & 5.72 & $-19 \%$ & $-2.34^{a}$ \\
\hline Refrigerated Juices & 21.09 & 17.12 & $-19 \%$ & $-3.10^{a}$ & 16.75 & 20.56 & $23 \%$ & 2.42 \\
\hline Soft Drinks & 71.10 & 63.51 & $-11 \%$ & -1.35 & 67.74 & 63.22 & $-7 \%$ & -1.08 \\
\hline Snack Crackers & 17.35 & 17.36 & $0 \%$ & 0.00 & 15.19 & 19.92 & $31 \%$ & $1.93^{\mathrm{b}}$ \\
\hline Canned Fish & 12.61 & 11.55 & $-8 \%$ & -0.85 & 11.94 & 10.39 & $-13 \%$ & $-1.99^{\text {b }}$ \\
\hline Toothpastes & 18.59 & 18.15 & $-2 \%$ & -0.25 & 14.15 & 12.93 & $-9 \%$ & -0.80 \\
\hline Toilet Tissues & 8.35 & 7.42 & $-11 \%$ & -1.27 & 8.08 & 7.14 & $-12 \%$ & -1.49 \\
\hline Total & 470.50 & 452.21 & $-4 \%$ & $-2.39^{a}$ & 392.93 & 376.28 & $-4 \%$ & $-2.56^{a}$ \\
\hline
\end{tabular}

Notes: Wholesale price (i.e., the cost) series come from the chain's database. They are computed as a weighted average of the amount the retailer paid for its entire inventory held in a given week.

As the holiday period in each year, we define the week before Thanksgiving through the week of Christmas, a total of six week period. The remaining weeks are defined as non-holiday periods.

Superscripts $a, b$, and $c$ indicate statistical significance at 1,5 , and 10 percents, respectively. 


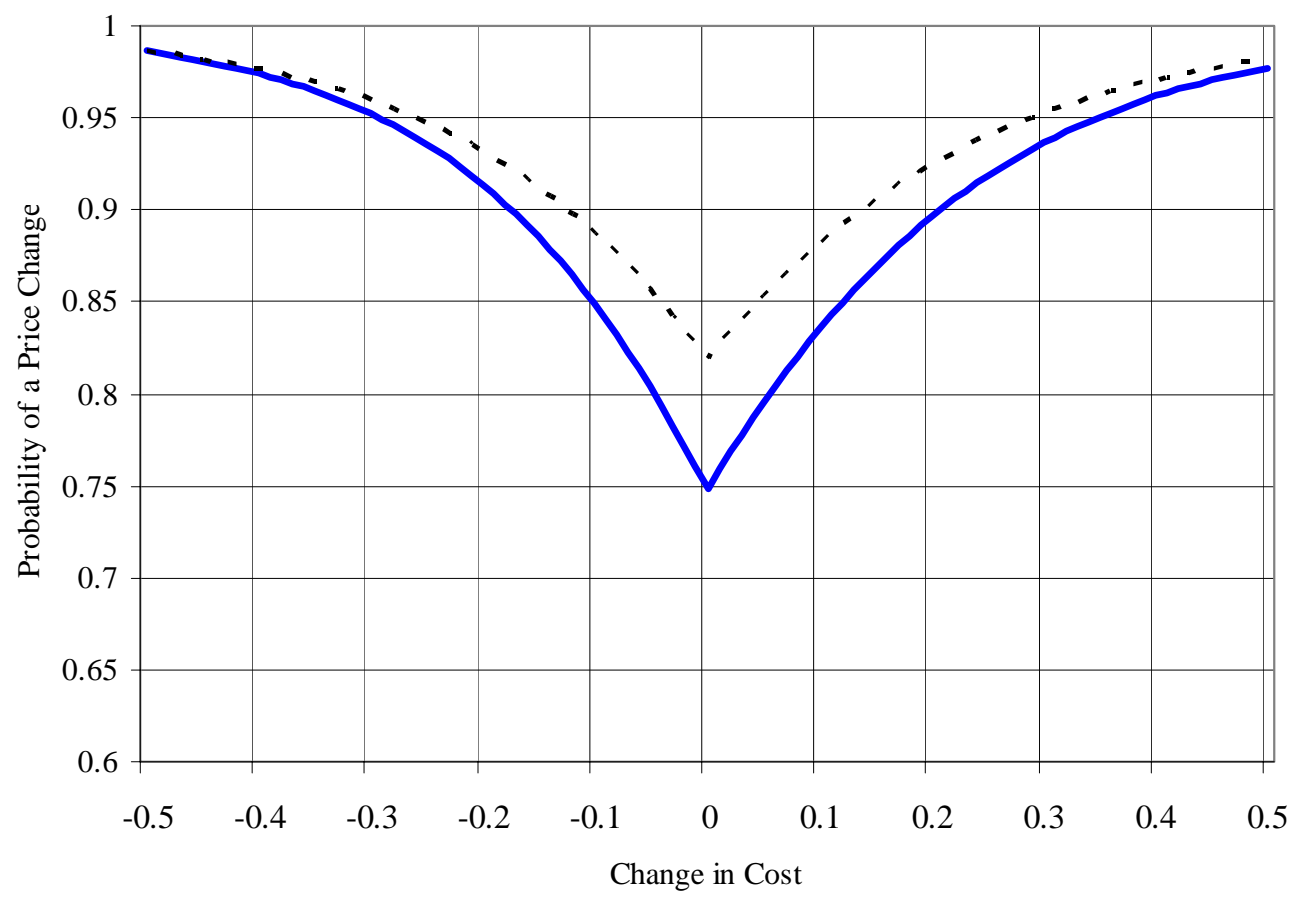

prob(price change): holiday - - - - prob(price change): non-holiday

FIGURE 1. CHANGE IN COSTS AND THE PROBABILITY OF A PRICE CHANGE DURING THE HOLIDAY AND NONHOLIDAY PERIODS, FROZEN ENTREES' CATEGORY

Note: The probability estimates are computed as deviations from the average values. 